\title{
Business Model Innovation towards Competitive Advantage: Case Study in Indonesian Cosmetics and Herbal Health Companies
}

\author{
*Anggraeni Permatasari, Wawan Dhewanto \\ Institut Teknologi Bandung, Indonesia \\ *anggraeni.p@sbm-itb.ac.id
}

\begin{abstract}
The dynamic changes in business environment make competition among company more tightly in the global market. This situation makes each company prepared innovation strategies to win global market competition. This research examined innovation strategies in two biggest cosmetic and herbal health companies in Indonesia. The author used case study with exploratory approach to find out how company developing innovation strategies and what factors that influence company in formulating those strategies. The author used canvas business modelling for analysis data. Data collection used secondary data which gained through the company profile and literatures review. This result indicates that innovation in value proposition, customer segments and key partners has become solution in helping cosmetic and herbal health industry strives to survive and be ready to face global business challenges.
\end{abstract}

Keywords: Innovation Strategies, Competitive Advantage, Globalization, Business Modelling, Cosmetic Industry

\section{Introduction}

Globalization cannot be avoided by many companies in the world. Ulrich Beck in Sheth and Sisodia (2002) state that "Accordingly, globalization is not only something that will concern and threaten us in the future, but something that is taking place in the present and to which we must first open our eyes." The company challenge in the era of globalization is how to be different and produced good quality products and services that can compete in the international market. The globalization will create crowded markets but it also creates new opportunities for companies. "Creating product differentiation will increase challenges for companies to rely on quality and innovation as key to their identity" (Davis, 2010). Peter Drucker in his book Management Challenges in 21st Century also states, "All institutions have to make global competitiveness a strategic goal" (Drucker, 1999, p61). Therefore, it is very important to plan the business strategy through innovation to win global market competition. The impact of globalization was also perceived by cosmetics and herbal health industry in Indonesia. The opening of worldwide free markets creates new challenges for Indonesian cosmetic companies to develop products. All companies' goals are to be superior in countered cosmetic products overseas. New product development can be the key for firm business success and innovation is its foundation (Ahn, 2004). This research discusses Indonesian cosmetics and herbal health companies in successfully developed and launched innovative business model to compete against global cosmetic companies. This research examines how cosmetics and herbal health company in Indonesia developed innovation business model towards competitive advantage in globalization and what are the factors that influence the success of innovation strategies conducted by them. "Strategy converts this theory of the business into performance. The purpose is to enable an organization to achieve its desired results in an unpredictable environment" (Drucker, 1999, p43).

\section{Literature Review}

Competitive Advantage: Competitive advantage is gained advantage over competitors to offer greater value to customers than competitors offer (Kotler, 2008). Competitive advantage shows the differences and uniqueness among competitors. There are two ways to achieve competitive advantage, which are: (1) Competitive advantage can be achieved if companies do charge a strategy that allows it to offer products at lower prices than competitors do. (2) Competitive advantage can also be achieved with a strategy of product differentiation so that customers perceive the benefits of the unique products that justify the high price. Both of these strategies have the same impact for improving the perceived customer benefits 
(Porter, 1995). According to this view, the company is able to develop a competitive advantage by creating value in the form and manner that is rarely or cannot be imitated by competitors (Barney and Wright, 1998). Therefore, that competitive advantage creates position superior to the competitors.

Innovation Strategies: The meaning of innovations is concatenate knowledge and creativity for creating new value in process, product or service. The value will give solution in a new way to do something. "Innovation developes in forms, products, services, market strategies, processes, and work practices, it also comes in other forms, such as marketing strategies, organizational designs, products, services, processes and techniques" (Amar and Januj, 2008). Innovation is never separated from the "novelty". There are two main aspects in an innovative novelty: first, the creation of new value, and second, there is new knowledge (Kadiman, 2008). "An innovative business is one which lives and breathes "outside the box". It is just not good ideas, it is combination of good ideas, motivated staff and an instinctive understanding of what your customer wants" (Tidd and Bessant, 2009). Innovation is fundamental strategy to produced competitive advantage in business competitiveness. Innovation strategy is the way in how companies create position in global market competition. "The focus on strategy content such as competitive position (or any other independent content concept, e.g. structure, size, degree of diversification, etc.) and its relation with performance became less interesting compared to research on how firms actually created the favorable positions over time" (Hedman and Kalling, 2003).

Business Modelling: Business model is how companies designed their business strategy as reflection of global changes. Every company have different model of business strategies, it needed to win global market competition. However, in the other hand, business model is more generic than a business strategy. "A good business model will provide considerable value to the customer and collect a viable portion of this in revenues. But developing a successful business model is insufficient itself to assure competitive advantage" (Tecee, 2010). Business model innovation is new way companies design their business strategies. It can be replicating or adapting new generation of strategies by comparing with previous strategy. Comparing the strategy are needed to design new business models meanwhile it still need analysis to protect the competitive advantage.

\section{Methodology}

This research used exploratory analysis approach with case study in two biggest cosmetic and herbal health companies in Indonesia, Martha Tilaar Group and PT.Mustika Ratu,Tbk. "Case studies are particularly good at enabling the researcher to get a detailed understanding the context of the research and the activity taking place within that context" (Saunders and Lewis,2012). The context in this study is finding business model innovation for global competitive advantage in cosmetics and herbal industry. Data was collected through secondary data which gained through the company profile in company website and literatures overview. The author used Canvas Business Model Analysis for data analysis. Canvas Business Model is tools that used to describe, analyze and design business model by building nine blocks, which are Customer Segments, Value Proposition, Channel, Customer Relationships, Revenue Streams, Key Resources, Key Partnerships, Key Activities and Cost Structure" (Osterwalder and Pigneur , 2010).

\section{Results}

\section{Company Profile}

PT. Martha Tilaar Group (MTG): Martha Tilaar Group (MTG) was traditional cosmetics founded by Dr. (H.C.) Martha Tilaar in 1970. The company was established in 1977 with the brand "Sariayu-Martha Tilaar". In 1981, for the first time, the modern manufactures cosmetics and herbal medicine builded. In 1986, the Company established a second modern factory. All products produced by Martha Tilaar Group have passed on research and constructed by modern technology equipment. . MTG have 11 subsidiaries to back up their performances. PT Martina Berto, Tbk and PT Cedefindo. With the ability to manufacture high-quality products and organize marketing strategies, the two companies are developing into a part of Martha Tilaar Group which is on its way to going global. Likewise, all Martha Tilaar Group products follow the international management standards of ISO9001, IS0140011.

\footnotetext{
${ }^{1}$ (www.marthatilaar.com)
} 
PT. Mustika Ratu, Tbk (PT.MR): PT Mustika Ratu (PT.MR) was founded in 1975 by Mooryati Soedibyo as a home industry specializing in the production of herbal remedies (jamu) and traditional cosmetics. In 1978, PT.MR started its commercial run, by producing herbs that are distributed to various regions of Indonesia. In the process of product development, consumer demand of the product increased, until in 1980 PT.MR began to develop various types of cosmetic and traditional herbs. In 1981, PT.MR factory authorized to operate. Integration began to implement international standards of ISO 9002 Quality Management System and ISO 14001 on Environmental Management Systems since 1996.

Canvas Business Modelling: Business model canvas is a concept that can be a broad language to reflect and present business model then create a new alternative strategy. The author have visualization of Business Model among companies in Figure1 and Figure2.

Figure 1: Canvas Business Model Martha Tilaar Group

\begin{tabular}{|c|c|c|c|c|}
\hline Key Partners & Key Activities & Value Proposition & $\begin{array}{l}\text { Customer } \\
\text { Relationships }\end{array}$ & $\begin{array}{l}\text { Customer } \\
\text { Segments }\end{array}$ \\
\hline \multirow{3}{*}{$\begin{array}{l}\text { Strong back } \\
\text { up by Group: } \\
11 \\
\text { Subisidiaries }\end{array}$} & Innovation & \multirow{5}{*}{$\begin{array}{l}\text { Product and Service: } \\
\text { Eastern Culture and } \\
\text { Value } \\
\text { Green Science/Natural } \\
\text { Product Design: new } \\
\text { packaging Marketing } \\
\text { online by social media } \\
\text { twitterandfacebook }\end{array}$} & & \multirow{5}{*}{$\begin{array}{l}\text { Diversified } \\
\text { market and } \\
\text { Segmentation } \\
\text { "East Meet West" } \\
\text { Virtual Customer } \\
\text { Psychological } \\
\text { segmentation }\end{array}$} \\
\hline & Centre: & & ner Service & \\
\hline & Science , & & Centre & \\
\hline $\begin{array}{l}\text { Subisidiaries } \\
\text { that have }\end{array}$ & $\begin{array}{l}\text { contest, CSR } \\
\text { Key Resources }\end{array}$ & & Channels & \\
\hline $\begin{array}{l}\text { their own key } \\
\text { partners in } \\
\text { local and } \\
\text { global } \\
\text { stakeholders }\end{array}$ & $\begin{array}{l}\text { Brand: NET-I3 } \\
\text { Professional HRD : } \\
6000 \text { employees } \\
\text { Strong Infrastructure }\end{array}$ & & $\begin{array}{l}\text { Strong } \\
\text { Distribution } \\
\text { Channels }\end{array}$ & \\
\hline \multicolumn{2}{|l|}{ Cost Structure } & \multicolumn{2}{|c|}{ Revenue Streams } & \\
\hline \multicolumn{2}{|c|}{ HRD, Technology, Promotion,Subsidiary } & \multicolumn{3}{|c|}{$\begin{array}{l}\text { Strong Financial Health: growing revenue, market } \\
\text { Share, product sales, subsidiary }\end{array}$} \\
\hline
\end{tabular}

Source: www.marthatilaar.com, www.detik.com

Figure 2: Canvas Business Model PT.Mustika Ratu

\begin{tabular}{|c|c|c|c|c|}
\hline Key Partners & Key Activities & $\begin{array}{l}\text { Value } \\
\text { Proposition }\end{array}$ & $\begin{array}{l}\text { Customer } \\
\text { Relationships }\end{array}$ & $\begin{array}{l}\text { Customer } \\
\text { Segments }\end{array}$ \\
\hline $\begin{array}{l}\text { Partnership } \\
\text { with } \\
\text { localandglobal }\end{array}$ & $\begin{array}{l}\text { R\&D: } \\
\text { Product } \\
\text { CSR }\end{array}$ & $\begin{array}{l}\text { Product: } \\
500 \quad \text { Personal } \\
\text { Care Product }\end{array}$ & $\begin{array}{l}\text { Strong Customer } \\
\text { Relationship }\end{array}$ & $\begin{array}{l}\text { Market } \\
\text { Segmentation: } \\
\text { Demography, }\end{array}$ \\
\hline $\begin{array}{l}\text { business } \\
\text { companies, }\end{array}$ & Key Resources & $\begin{array}{l}\text { Service and } \\
\text { Tradisional }\end{array}$ & Channels & $\begin{array}{l}\text { Cohort Analysis, } \\
\text { Life Style, Life }\end{array}$ \\
\hline $\begin{array}{l}\text { university } \\
\text { (developing } \\
\text { research) }\end{array}$ & $\begin{array}{l}\text { Strong } \\
\text { Image, } \\
\text { Infrastructure }\end{array}$ & $\begin{array}{l}\text { Herbal Medicine } \\
\text { Natural Product } \\
\text { Marketing online }\end{array}$ & $\begin{array}{l}21 \quad \text { Distribution } \\
\text { Channel, } 26 \text { spa } \\
\text { fanchise }\end{array}$ & $\begin{array}{l}\text { Cycle Customer, } \\
\text { Strong } \\
\text { Image and New } \\
\text { Packaging }\end{array}$ \\
\hline
\end{tabular}

Cost Structure

HRD, Technology, Promotion
Revenue Streams

Financial Health: growing revenue, market Share, Sales product

Source: www.mustika-ratu.co.id, www.mustikaratu.com, Hurul 2011

Customer Segments: Customer segment describes the company wishes to reach or serve different groups of people or organizations (Osterwalder and Pigneur , 2010). MTG and PT.MR have different strategies in customer segments. MTG used diversification segments and PT.MR used market segmentation.

MTG Strategies: MTG has developed customer segments by gaining diversified as competitive advantage in both local and global cosmetic industry. Diversification is the customer's business model that serves two customer segments (Osterwalder and Pigneur, 2010). MTG regarding strongly believes in the concept implementation benefits. The concept is objected to benefit the stakeholders, shareholders, employees, 
end consumers and the community as a whole. So the strategies that MTG implemented was divided the markets into :

- Age Segmentation: Teenagers (15 years) to Mature ( $>40$ years)

- Gender Segmentation: Male and Female

- Class/ Price Segmentation: A (premium), B (upper middle), C (middle), D (lower middle)

- Psychology Segmentation: (1) Natural and Eastern Image (2) Modern Image.

PT.MR Strategies: PT.MR strategies are different from MTG. PT.MR was prefer used market segmentation. Market segmentation are business model that distinguishes each segments of the market needs and problems. (Osterwalder and Pigneur,2010) PT.MR continued to make innovations in herbal product to meet market needs. Currently, PT. MR has been producing various types of products consisting of hair care, facial care, body care, make-up foundation, make-up artistic and herbs for all kinds of age or gender. PT.MR advantages compared to competitors are they have loyal customers. PT.MR market segmentation are demography characteristic, gender, cohort analyze, behavior seen by age group $<15$, $15-19,19-45,>45$, life cycle customer and life style (Sudibyo,2010).

Value Proposition: Value proposition describes the combination of products and services that create value for specific customer segments. "Value proposition used to create value for the customer segments through a blend of different elements that serve the needs of these segments" (Osterwalder and Pigneur ,2010). Actually, the value proposition that both companies done was same, they used eastern traditional value as competitive advantages and new product design including up to date packaging. The difference can seen in their product focus and technology , MTG focusing in cosmetic products and face care with high technology but PT.MR have more focus in herbal health medicine and body care product with low technology.

MTG Strategies: MTG's value proposition is arising value of NET-I3. NET stands for Natural, Eastern, Technology; I3 stands for Icon, Innovation and Institution. The concept of NET highlights the uniqueness of the brand and business development concept, whereas its product range is enriched with eastern traditional values and is designed with the use of modern technology. The product resulted by issuing classy cosmetic products such as; Biokos, Belia, Caring Colors, Professional Artist Cosmetics (PAC), Aromatic, Medicinal Garden and others that are well known to foreign countries. Martha Tilaar then builds Puri Ayu Martha Tilaar, an herbal medicine and cosmetics stores that cater to the upper middle class.

PT.MR Strategies: PT.MR strategies in value proposition is developing herbal remedies encompass Jamu Mustika Ratu, Jamu Jagaraga and fresh remedies and traditional cosmetic lines consist of facial, body, skin and hair care. The resulting product is Mustika Ratu, Mustika Putri, Bask, Ratu Mas, Moors's and Taman Sari Royal Heritage Spa. Taman Sari Royal Heritage Spa managed franchise systems for service products in body care and treatment. Taman Sari Royal Heritage Spa creating benefits in quality service products. The service product processed using modern technology with materials natural ingredients.

Channels: "Channel describes how the company communicates with customers and reaches out those segments to deliver the value proposition" (Osterwalder and Pigneur , 2010). The types of channels that used by the two companies have much in common such as, sales man, web-sales, store, partner store and distribution. The both companies also developed channel in overseas to fulfill global market. The difference are MTG organized in a part of group, which MTG have their own subsidiaries in distribution meanwhile PT.MR distribution channel are partnership with other companies.

MTG Strategies: MTG channel distribution such as (a) Modern trade channels including online stores, chain stores and supermarkets, (b) Conventional trade including wholesalers, cosmetic retailers, beauty salons and spas, (c) Marketing channels with specialty stores in selected locations across Indonesia and abroad. MTG recently opened the first Martha Tilaar specialty store in Singapore, (d) Also operates speciality stores and direct promotion force creating new market demand. "Extensive presence in the Indonesian market with a line presence across marketing channels exports to in Malaysia, Singapore, Brunei Darussalam, Philippines, Japan, Hong Kong, and Taiwan in Asia, Greece, the Middle East"2 .

\footnotetext{
${ }^{2}$ (www.martinaberto.co.id)
} 
PT.MR Strategies: Currently, PT.MR have 20 distributors in Java and one's distributor outside Java, two outlets in local and two outlets international. PT.MR also has an extensive distribution network, in several branches in major cities in Java coupled with dozens of distributors throughout Indonesia and abroad, making the products - its spread to almost every type of outlet both traditional and modern markets. For examples Taman Sari Royal Heritage Spa has 26 franchises and branches both in the country and abroad with International standard therapist. With its high quality service, Taman Sari Royal Heritage Spa has received numerous awards both locally and overseas, thus making Taman Sari Royal Heritage Spa to the Best Spa Destination International level.

Customer Relationships: "Customer relationships describe the different types of relationships that company built with specific customer segments" (Osterwalder and Pigneur , 2010). In global competition customer is the core of all business models, without customers there is no company that can survive for a long time. The customer relationship strategies that both company done mostly have same patterns. Both companies have same focused in customer satisfaction. The relationships managed by website, events, meet and greets, customer service and call centre. The difference are PT.MR also give healthy tips and herbal medicine campaign to build relationships intensely.

Revenue Streams: Revenue streams describe the revenue generated from the company's customer segments. There are two types of revenue; first, revenue generated from a one-time customer payment and second, recurring revenues generated from ongoing payments for providing value proposition to customers and customer support after sales (Osterwalder and Pigneur ,2010). So based on company profile, both companies maintain their revenue streams in two types of revenue; such as product sales, market share, commission fees and license for franchise.

MTG Strategies: In 2009, MTG had a market share of 2.5\% in beauty and personal care products, $13.6 \%$ in color cosmetics and 5.7\% in skin care products in Indonesia. MTG achieves revenue of IDR $566.2 \mathrm{bn}$ (US $\$ 63.4 \mathrm{~m}$ ) in 2010, with a YoY growth of $9.7 \%$ over 2009 The gross and operating margins currently stand at $53.3 \%$ and $9.14 \%$ respectively and have consistently rising in the last few years. (www.martinaberto.co.id)

PT.MR Strategies: Meanwhile, PT.MR revenue streams according to the Consolidated Non-Audited financial statement for the first two cumulated quarters of 2012, total net operating revenues increased with $10.47 \%$. The results of the period increased $71.52 \%$ from last year. ${ }^{3}$

Key Resources: "Key resources describe the most important assets required to make a business model work out. Key resources can take the form of physical, financial, intellectual or human" (Osterwalder and Pigneur , 2010). Based on the history, both companies have a same key resources such as modern manufactures, plantation, professional human resources and branding. In human resources, the both companies intensively developed training to increase motivation and improve employees' work ability. The differences are MTG refers to the Group's success as a leading traditional cosmetic brand due to its capability of highly respecting professionalism and controlling the quality of its products and services also distribution. MTG have 6.000 employees to back up their performances. But on the other hand PT.MR constantly improves the company's performance by adopting ISO 9001 version 2000 to improve the quality of products to increase customer satisfaction.

Key Activities: "Key activities describe the most important things that must be done in order to grow its business model" (Osterwalder and Pigneur ,2010). The succes of the new product in MTG and PT.MR cannot separate from innovation in research and development (R \& D). The both companies have full commitment in building R \& D centre of innovation to create green and natural product that save for consumers and environmental sustainability. They also build plantations procures raw materials for its various product lines in West Java. For promotion both companies have a same activities in supporting beauty contest for Indonesian woman to compete with other beauty contestant in the world. The strategies are a commitment that must be developed to introduce the beauty of traditional eastern values and cultures to the world. Both companies also doing corporate social responsibility (CSR) as main

\footnotetext{
${ }^{3}$ (www.securities.com)
} 
activities in empowering women and environmental sustainability. The CSR activities are supported MDG'S goals for sustainability development in 3P (People, Profit and Planet).

Key Partnerships: "Key partnerships describe the network of suppliers and partners to make the business model work out" (Osterwalder and Pigneur , 2010). MTG have three key partnerships such as academic, business and government. " Erlisativani, Corporate Communications Manager MTG, adding, now every year more than 150 items of products have been produced MTIC. MTIC is according to Erli successfully combines the three aspects at once: academic, business and government, in order to obtain a product that could actually received by the market at once recognized by the government and academia. As a result, some of the findings of MTIC successful products in the market exploded" (Swa magazine,2009). This strategies is almost the similar with PT.MR but the difference are MTG work as a group. The subsidiaries management have their owned key partners. PT MR opened engagement to all business sector but the management still centralized.

Cost Structure: This building block describes the most important costs that arise when operating a particular business model. Cost business model divided into two classes; cost-driven and value-driven, many business models that are in between them (Osterwalder and Pigneur , 2010). The both companies have similar cost structure such as fixed cost in sallary, fabrication, R\&D. The difference are in variabel cost and operational such as promotion and channel distribution. Cost structure in technology extremely different between MTG and PT.MR in developing services and products, which is MTG prefer to used high technology but PT.MR still used standard technology. This is done to reduce the cost of production and operational costs. But in the other hand, technology become competitive advantage in design and product packaging for both companies in promoting of new products and build a brand image among the general public.

Centre of Innovation Business Model: Innovation discussed when a new product, a new system, a new state-of products, systems, better conditions and valuable and desirable. Innovation concern when creating new values as desired. Innovation discussed when a new product, a new system, a new state-of products, systems, better conditions and valuable-desirable. (Kadiman,2008).

MTG Centre of Innovation: Martha Tilaar Group has successfully implemented diferentiation in product innovation as competitive advantage to compete with international cosmetic products. "Martha Tilaar brand of cosmetics for Indonesian and International markets has been operational for more than 30 years and becomes one of the leading national cosmetics manufacturing company" (www.martinaberto.co.id)

Figure 3: Centre of Innovation MTG

\begin{tabular}{|c|c|c|c|c|}
\hline $\begin{array}{l}\text { Key } \\
\text { Partners }\end{array}$ & $\begin{array}{l}\text { Key } \\
\text { Activities }\end{array}$ & $\begin{array}{l}\text { Value } \\
\text { Proposition }\end{array}$ & $\begin{array}{l}\text { Customer } \\
\text { Relationships }\end{array}$ & $\begin{array}{l}\text { Customer } \\
\text { Segments }\end{array}$ \\
\hline \multirow{2}{*}{3} & & 2 & & \\
\hline & ney & & Channels & \multirow[t]{2}{*}{1} \\
\hline \multicolumn{2}{|c|}{ Cost Structure } & \multicolumn{2}{|c|}{ Revenue Streams } & \\
\hline
\end{tabular}

SWA Magazine (2009) in article Martha Tilaar is the best innovation in ASEAN state that "Traditional innovation that MTG offered can compete with technological innovation which is contrasted with another company of Singapore Technologies Engineering Ltd. which became one of the finalists. The strength of the quality product innovation could be a mainstay during the run with the strategy right and the right steps. Innovation does not have to be read from the technology, but also for the extraction of natural resources and innovation in the global market segment." Innovations conducted by MTG triggered by three center building blocks that very influential for others (Figure 3). The three innovations which looks very supportive of the business occurs at the point of customer segments, value proposition and key partners.Wular Tilaar, Director of Martha Tilaar Salon and Vice Chair Woman in MTG, in exclusive 
interview also stated innovation strategy that used by MTG in addressing the current challenges. Innovation strategy that used to conduct product promotion abroad and Martha Tilaar Store opening more both at home and abroad, are also using social media such as twitter, facebook etc, product packaging is also made better and attractive, but that she also developed human resources by sending his servants abroad. "Today, more competitors, not only local Indonesian Brand but also International Brand. Now, it's a lot and the quality is very good and the challenge is how can it continue to innovate to meet the needs of the market."4.

PT.MR Centre of Innovation: PT.Mustika Ratu central innovations encouraged by creating new value proposition through innovative products and services. In product and service innovation, PT.MR as a leading producer of traditional cosmetics in Indonesia, with special emphasis on the secondary market. Focusing on a major expansion in this segment, the company grew faster and produced more than 500 kinds of cosmetic products. President Director of PT.MR, Putri K stated that "PT. MR as a traditional herbal medicine and cosmetic used natural ingredients Indonesia with modern processing but left no cultural roots Nations. As a company that has to go international, PT.MR remains consistent in maintaining the noble values of the culture that has been passed down from generation to generation." 5

Figure 4: Centre of Innovation PT.MR

\begin{tabular}{|c|c|c|c|c|}
\hline $\begin{array}{l}\text { Key } \\
\text { Partners }\end{array}$ & $\begin{array}{l}\text { Key } \\
\text { Activities }\end{array}$ & $\begin{array}{l}\text { Value } \\
\text { Proposition }\end{array}$ & \begin{tabular}{|l|} 
Customer \\
Relationships \\
\end{tabular} & $\begin{array}{l}\text { Customer } \\
\text { Segments }\end{array}$ \\
\hline & $\begin{array}{l}\text { Key } \\
\text { Resources }\end{array}$ & & Channels & 1 \\
\hline \multicolumn{2}{|c|}{ Cost Structure } & \multicolumn{3}{|c|}{ Revenue Streams } \\
\hline
\end{tabular}

PT.MR proudly received Economic Challenge Award 2011 in the category of cosmetics. This shows Mustika Ratu products received recognition from the local community as a product of the most beloved cosmetic. PT.MR will continue to maintain and continuously improve the quality of products so the brand became the pride of Indonesia domestic products. Through the centre of innovation business model analyse in Figures 3 and 4, it can be seen that the two companies' have same innovation strategy based on value proposition and customer segments. From directional arrows causal relationship exists between the value proposition, customer segments and key partners. The difference are MTG focus on innovation cosmetic product but PT.MR focus on developing innovation in herbal health product. The Eastern Culture as multicultural in nature, is a blending of great world civilizations, perceives woman and beauty as a two-sided coin, whereas an everlasting natural beauty is a balanced combination between inner and outer beauty. Martha Tilaar is a big companies group, so forms of consolidated companies made MTG to develop more integrated in holistic innovation center point. Especially for managing key resources, key channel activity to have efficient cost structure and increases revenue streams.

The other factor that important to win global market competition is customer segmentation strategies. Customer segmentation strategies that implemented by Martha Tilaar Group and PT. Mustika Ratu quite diferrent. The interesting is how they create marketing strategy in market positioning. The strategy was fulfilling two market segmentation with different type of product innovation. The MTG strategy become more unique because eastern product have position in global market and western product become favorite for local consumer. But PT.MR focused in fulfill middle segmentation with mix product between traditonal and modern. Business model innovation is not about looking at competitors. Business innovation is not about imitating or compare, but it's about creating new mechanisms to create value and earn revenue (Osterwalder and Pigneur, 2010). Looking from the best center of innovation that has been carried out by two of the biggest cosmetic companies in Indonesia, the author suggested business model

\footnotetext{
4 (www.wolipop.detik.com)

5 (www.mustikaratu.com)
} 
strategy that can be used for cosmetics and herbal health company to develop new business strategy to win the global market competition (Figure 5).

Figure 5: Bussiness Model Strategy Proposed

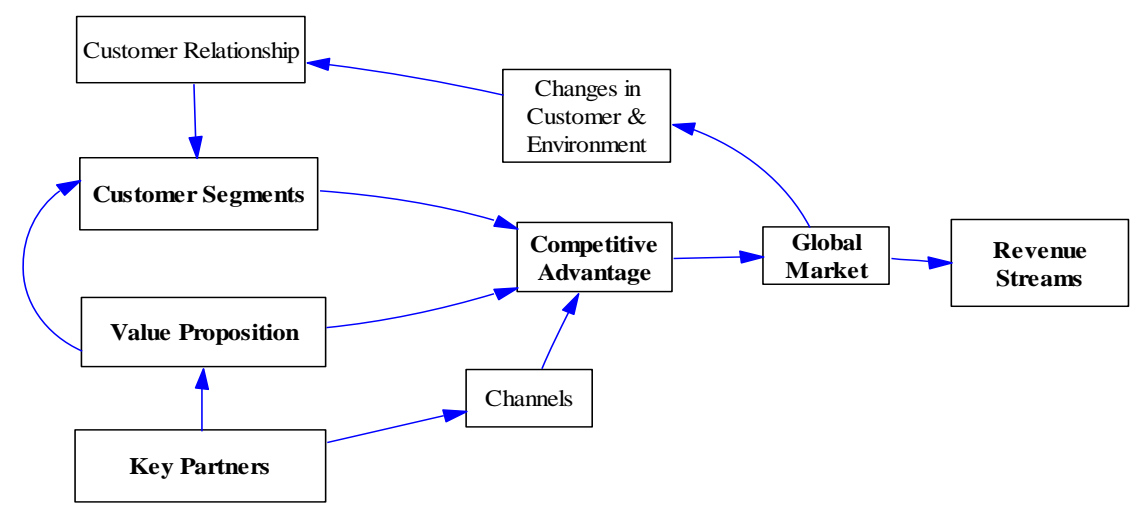

\section{Conclusion}

Based on business model innovation strategies that build by two biggest companies in cosmetic and herbal health companies, innovation strategies in value proposition, customer segmentation and key partners creates global competitive advantages to the cosmetics and herbal health industry in Indonesia. Cosmetic and Herbal Health Industry in Indonesia had been succesfully compete against global cosmetic brands by differentiation as competitive advantage. Both companies are improving diffrentiation in value creation by developing products based on Indonesia natural and cultural wealth (local wisdom). The companies become unique and superior so they can compete with the global cosmetics company.

Recommendation: Based on the result, in a similar industrial competition, especially in Small Medium Enterprises (SME), companies must be able to create different product characteristics and has a special image in the eyes of consumers. Competition industry in similar product is often faced with competition among competitor. So to be able to survive in the globalization, companies must prepared and required innovation in bussines model as a strategies to win global competition. Developing innovation in value proposition, market segmentation and key partner was become absolute key factor in global market competition.

\section{References}

Ahn, S. H. (2004). Integrating Technology, Marketing and Management Innovation, Research Technology Management; Jul/Aug 2004; 47(4), 27

Amar, D. \& Januj, A. (2008). Descriptive model of innovation and creativity in organizations, Knowledge Management Research andPractice No.6, 298-311Bannet, P(1988). Dictionary of Marketing Terms, Chicago American Marketing Association

Barney, J. B. \& Wright, P. M. (1998). On Becoming a Strategic Partner : The Role of Human Resource in Gaining Competitive Advantage. Human Resources Management, 37(1), 31-46

Davis, J. A. (2010). Competitive Success: How Branding Adds Value, Wiley

Drucker, P. (1999). Management Challenges for 21st Century, Perfect Bound

Hedman, J. \& Kalling, T. (2003). The business model concept: theoretical underpinnings and empirical illustrations. European Journal of Information Systems, 12, 49-59

Hurul, L. (2011). Strategi Manajemen Mustika Ratu, Manajemen Bisnis Telekomunikasi dan Informatika,Institut Manajemen Telkom

Kadiman, K. (2008). Simfoni Inovasi, Cita and Realita, Foresight

Kotler, P. (2008). Principle of Marketing, Pearson Education, Prentice Hall

Osterwalder, A. \& Yves, P. (2010). Business Model Generation, PT.Elex Media Komputindo

Porter, M. E. (1995). Competitive Advantage : Creating and sustaining superior Performance, New York: Simon and Schuster. Inc

Saunders, M. \& Lewis, P. (2012). Doing Research in Business and Management: An Essential Guide to Planning Your Project, Pearson Education Limited 
Sheth, J. \& Sisodia, R. (2010). The Rule of Three: Surviving and Thriving in Competitive Markets, Free Press

Sudibyo, M. (2010). Family Business Responses to Future Competition, Gramedia

Tilaar, M. (2012). Pioneers in Green Science, Dian Rakyat

Tecee, D. J. (2010). Business Models, Business, Strategy and Innovation, Long Range Planning 43, 172e194

Tidd, J. \& Bessant, J. (2009). Managing Innovation: Integrating Technological, Market and Organizational Change, 4th Edition, Wiley

Martha Tilaar Company Profile, 28 February 2013, Retrived from www.marthatilaar.com

Mustika Ratu Company Profile, 28 February 2013, Retrived from www.mustika-ratu.co.id

Communication on Progress PT.Martina Berto 2010, Martha Tilaar Group, 20 May 2011, Retrieved from www.martinaberto.co.id

Swa Magazine, Inovasi Martha Tilaar Terbaik di ASEAN, 2 April 2009, Retrieved from http://swa.co.id

EMIS TM, Kosasih and Nurdiyaman. (2005). Emerging Market Information Retrieved from http://www.securities.csom/Public/companyprofile/ID/Mustika_Ratu_Tbk_PT_en_1611496.htm l

Oktaviani, Kiki, Intimate Interview:Selami Bisnis Spa, Wulan Tilaar Sekolah Pijat and Kecantikan, 31 July 2012, Retrieved from http://wolipop.detik.com 